\title{
Effect of gaseous hydrochloric acid on human and bovine enamel
}

\author{
- Juliana dos Reis Derceli Centro Universitário da Fundação Educacional de Barretos (UNIFEB), Barretos, SP, Brazil • \\ Juliana Jendiroba Faraoni Department of Restorative Dentistry, School of Dentistry of Ribeirão Preto, University of São \\ Paulo (USP), Ribeirão Preto, SP, Brazil • Pâmella Coelho Dias Department of Restorative Dentistry, School of Dentistry \\ of Ribeirão Preto, University of São Paulo (USP), Ribeirão Preto, SP, Brazil • Laís Lopes Machado de Matos Department \\ of Restorative Dentistry, School of Dentistry of Ribeirão Preto, University of São Paulo (USP), Ribeirão Preto, SP, Brazil • \\ Regina Guenka Palma-Dibb Department of Restorative Dentistry, School of Dentistry of Ribeirão Preto, University of São \\ Paulo (USP), Ribeirão Preto, SP, Brazil
}

ABSTRACT | Objective: To evaluate the action of gaseous hydrochloric acid on human and bovine enamel and compare the demineralization pattern of these substrates exposed to the gaseous erosive agent. Methods: Eight bovine enamel and eight human enamel specimens were obtained $(4 \times 4 \times 2 \mathrm{~mm})$, half surface was protected with composite resin and the other half was exposed to gaseous hydrochloric acid $(\mathrm{gHCl}), \mathrm{pH} 2$ at $37^{\circ} \mathrm{C}$, for $3 \mathrm{~min}$, 8 times a day, for 12 days, and in intervals the specimens were maintained in artificial saliva. The specimens were analyzed according to wear profile, surface roughness and microhardness (before and after acid exposition). Data were statistically analyzed by one-way ANOVA. Results: Data showed no significant difference between bovine and human enamel for all properties analyzed - microhardness (98.1 $\pm 5.2,96.9 \pm 4.8$ ), wear profile (11.5 $\pm 2.8,11.4 \pm 3.6)$ and roughness $(2.6 \pm 0.3,3.3 \pm 0.3)$, respectively. In images, we observed that $\mathrm{gHCl}$ could cause enamel erosion in both groups. Conclusion: Gaseous hydrochloric acid causes similar enamel erosion on bovine and humans.

DESCRIPTORS | Dental Enamel; Gastric Acid; Gastroesophageal Reflux Disease.

RESUMO | Efeito do ácido clorídrico gasoso no esmalte humano e bovino • Objetivo: Avaliar a ação do ácido clorídrico gasoso sobre o esmalte humano e bovino e comparar o padrão de desmineralização desses substratos expostos ao agente erosivo gasoso. Métodos: Oito espécimes de esmalte bovino e oito de esmalte humano foram obtidos $(4 \times 4 \times 2 \mathrm{~mm})$, metade da superfície foi protegida com resina composta e a outra metade exposta ao ácido clorídrico gasoso ( $\mathrm{gHCl}$ ), $\mathrm{pH} 2$ a $37^{\circ} \mathrm{C}$, por 3 min, 8 vezes ao dia, durante 12 dias, e em intervalos os espécimes foram mantidos em saliva artificial. Os espécimes foram analisados quanto ao perfil de desgaste, rugosidade superficial e microdureza (antes e após a exposição ao ácido). Os dados foram analisados estatisticamente por ANOVA de uma via. Resultados: Os dados não mostraram diferença significativa entre o esmalte bovino e humano para todas as propriedades analisadas - microdureza $(98,1 \pm 5,2,96,9 \pm 4,8)$, perfil de desgaste $(11,5 \pm 2,8,11,4 \pm 3,6)$ e rugosidade $(2,6 \pm 0,3,3,3 \pm 0,3)$, respectivamente. Nas imagens, observou-se que gHCl pode causar erosão do esmalte em ambos os grupos. Conclusão: O ácido clorídrico gasoso causa erosão do esmalte de forma semelhante em bovinos e humanos.

DESCRITORES | Esmalte Dentário; Ácido Gástrico; Doença do Refluxo Gastroesofágico.

CORRESPONDING AUTHOR | • Regina Guenka Palma-Dibb Department of Restorative Dentistry, School of Dentistry of Ribeirão Preto, University of São Paulo (USP), • Avenida do Café, s/n Ribeirão Preto, SP, Brazil. • 14040-904 E-mail: rgpalma@usp.br

- Received Jun 09, 2020 • Accepted Jun 09, 2020

- Dol http://dx.doi.org/10.11606/issn.2357-8041.clrd.2020.171222 


\section{INTRODUCTION}

According to recent studies, the gastroesophageal reflux disease (GERD) is the most common gastrointestinal related diagnosis. ${ }^{1-3}$ GERD is a multifactorial disease, and the transient lower esophageal sphincter relaxation is the main mechanism of gastroesophageal reflux in normal subjects ${ }^{4}$ and in the patients with reflux disease. ${ }^{5}$

Normal subjects with a functional antireflux barrier presented few episodes of physiologic acid reflux; ${ }^{6}$ however, patients with reflux disease have these episodes more often, ${ }^{7}$ suggesting a deficient antireflux barrier. ${ }^{8}$ Refluxate is composed of liquid acid, gas, mixed liquid-gas, ${ }^{9}$ with frequent presence of gas during episodes of reflux..$^{10,11}$

The Impedance-pH monitoring is a gold-standard method for diagnosis and monitoring of the gas present in reflux episodes and thus associated with disease symptoms. ${ }^{12-16}$

Recent studies that analyzed the pressure associated with reflux have also been interpreted, indicating that most reflux episodes are associated with belching. ${ }^{17-19}$ Gas reflux occurs in most episodes in patients with reflux disease. ${ }^{19}$ It is important to note that not all gas reflux episodes are considered as belching. ${ }^{11}$

The intrinsic dental erosion is likely caused by gastric acid reflux into the oral cavity. ${ }^{20}$ Gastric contents (hydrochloric acid and pepsin) ${ }^{21}$ have a low pH near 2.7 and can induce enamel demineralization, the formation of erosive lesions ${ }^{20}$ in rats proved that the association between gastric acid reflux and orals diseases exists. ${ }^{20}$ With the erosive potential of hydrochloric acid comes the need to evaluate the action of gaseous hydrochloric acid and study the effect of this gas on dental enamel, considering the many reports about the existence of the gas and the high incidence of gaseous reflux episodes in patients with GERD ${ }^{22}$.

Bovine teeth are widely used in studies to analyze the effect of various conditions on enamel and have a good reproducibility of results when comparing with human teeth. ${ }^{23,24}$ However, the action of gaseous hydrochloric acid on bovine and human enamel is unknown, and the effects can be different because the chemistry and structure of both enamels are not identical. ${ }^{25,26}$

Thus, the aim of this study was to evaluate the action of gaseous hydrochloric acid on human and bovine enamel and to compare the demineralization pattern of these substrates exposed to gaseous erosive agent.

\section{MATERIALS AND METHODS}

\section{Experimental Design}

For this study, we used eight bovine enamel specimens (incisive buccal face) with a dimension of $4 \times 4 \times 2 \mathrm{~mm}$ and eight human enamel specimens (molar buccal face). The specimens were exposed to gaseous hydrochloric acid for 12 days. After the erosive challenges, the specimens were analyzed according to wear profile, step, surface roughness and microhardness.

\section{Sample Preparation}

This study was approved by the local Ethics Committee involving human teeth (protocol no. 2011.1.1271.58.2). To obtain the fragments clean bovine incisors and human molars were employed, which were stored in $2 \%$ formaldehyde solution at $\mathrm{pH}$ 7.o. The teeth with cracks, hypoplasia stains or severe wear were discarded. The teeth were cut at the cement enamel junction by a water-cooled diamond saw in a sectioning machine. The bovine crowns were bisected longitudinally, and the buccal and lingual fragments were separated; the lingual fragment was discarded, providing buccal enamel specimens $(4 \times 4 \times 2 \mathrm{~mm})$. The human crowns were cut in the mesio-distal direction, and the buccal face was used.

The bovine specimens were delineated and polished due to their irregular surface with water and sandpaper (granulation \#600 and \#1200), felt discs and alumina suspension (0.3 and $0.05 \mu \mathrm{m})$. The human specimens were not delineated and polished. 
All specimens were selected by baseline surface microhardness (KHN), which was determined using the average values of five indentations performed at distances of $500 \mu \mathrm{m}$ from each other (Knoop diamond, 25 g/f, 10 s, Shimadzu Micro Hardness Tester HMV-2.00o), a mean microhardness value was calculated, and the sample presenting a $\pm 20 \%$ mean microhardness was included in this study. Eight bovine and eight human fragments were selected.

All the fragments selected were coated with composite resin (reference area), ${ }^{27}$ leaving half of the enamel surface without protection to apply the erosive challenge.

\section{Erosive Challenge}

All specimens were fixed in a glass plate with wax and exposed to gaseous hydrochloric acid in a closed device with $\mathrm{pH} 2$ at $37^{\circ} \mathrm{C}$, for $3 \mathrm{~min}, 8$ times a day, for 12 days. Between erosive challenges, the specimens were immersed and stored in artificial saliva ${ }^{27}$ at $37^{\circ} \mathrm{C}$. The artificial saliva was changed daily.

To perform the erosive challenges, we used a glass device able to maintain the system closed with temperature and $\mathrm{pH}$ monitored by a thermometer and $\mathrm{pH}$-indicator paper, respectively.

Inside the device na $\mathrm{HCl}$ solution was placed, which was heated by a magnetic stirrer. The heated $\mathrm{HCl}$ solution made gaseous $\mathrm{HCl}$, which was in contact with enamel fragments by a predetermined period ${ }^{27}$. All the fragments were exposed to gas simultaneously.

\section{Wear profile, surface roughness and surface morphology analysis}

After careful removal of composite resin used to isolate the fragments, they were subjected to wear profile and surface roughness analyses.
The analyses were performed by a confocal laser microscope (Olympus LEXT OLS4000 ${ }^{\circledR}$, Japan), through which $3 \mathrm{D}$ enamel surface images were obtained. Measurements were performed using specific software.

Ten measurements were performed on each specimen, which roamed the reference and eroded areas. Wear profile (Rv in $\mu \mathrm{m}$ ), Step (high in $\mu \mathrm{m}$ ), and surface roughness ( $\mathrm{Ra}$ in $\mu \mathrm{m}$ ) were observed.

\section{Longitudinal Microhardness}

After erosive challenges, the fragment side was delineated and polished with water and sandpaper (granulation \#600 and \#1200), felt discs, and alumina suspension (0.3 and $0.05 \mu \mathrm{m})$. Microhardness analysis was performed in the reference and eroded areas. In each area, nine Knoop indentations were made in three columns, at distances of 30,60 and $90 \mu \mathrm{m}$ from the edge ( $25 \mathrm{~g} / \mathrm{f}, 10 \mathrm{~s})$, and a mean microhardness value was calculated per specimens.

\section{Data analysis}

After homogeneity and normal distribution evaluation, data were analyzed by one-way analysis of variance (ANOVA) at 5\% level. The software SigmaStat (Windows version 3.5, Systat Software Inc.) was used for the calculation.

\section{RESULTS}

Data showed there was no significant difference between bovine and human enamel and microhardness (Table 1), wear profile, step and roughness analysis (Table 2). Analyzing the data and the $3 \mathrm{D}$ images (Figure 1) we observed that $\mathrm{gHCl}$ was able to cause enamel erosion in both groups. 
TABLE 1 | Mean $(\mu \mathrm{m})$ and standard deviation values of microhardness of the subsurface enamel.

\begin{tabular}{c|c|c|c|c} 
& \multicolumn{2}{|c|}{ Bovine } & \multicolumn{2}{c}{ Human } \\
\hline & Control & Eroded & Control & Eroded \\
\hline $30 \mu \mathrm{m}$ & $260.00 \pm 69.77$ & $250.17 \pm 70.98$ & $256.14 \pm 38.59$ & $266.71 \pm 45.93$ \\
\hline $60 \mu \mathrm{m}$ & $276.28 \pm 66.79$ & $273.72 \pm 91.89$ & $266.90 \pm 44.60$ & $250.67 \pm 34.10$ \\
\hline $90 \mu \mathrm{m}$ & $281.89 \pm 64.32$ & $277.22 \pm 77.72$ & $278.90 \pm 46.60$ & $253.67 \pm 34.67$ \\
\hline
\end{tabular}

TABLE 2 | Mean $(\mu \mathrm{m})$ and standard deviation (SD) values of the surface enamel wear profile, step and roughness of experimental groups.

\begin{tabular}{c|c|c|c}
\hline Experimental group & Wear profile & Step & Roughness \\
\hline Bovine & $10.5 \pm 3.95$ & $14.25 \pm 5.34$ & $2.6 \pm 0.94$ \\
\hline Human & $11.4 \pm 3.63$ & $16.92 \pm 6.53$ & $3.3 \pm 0.70$ \\
\hline
\end{tabular}

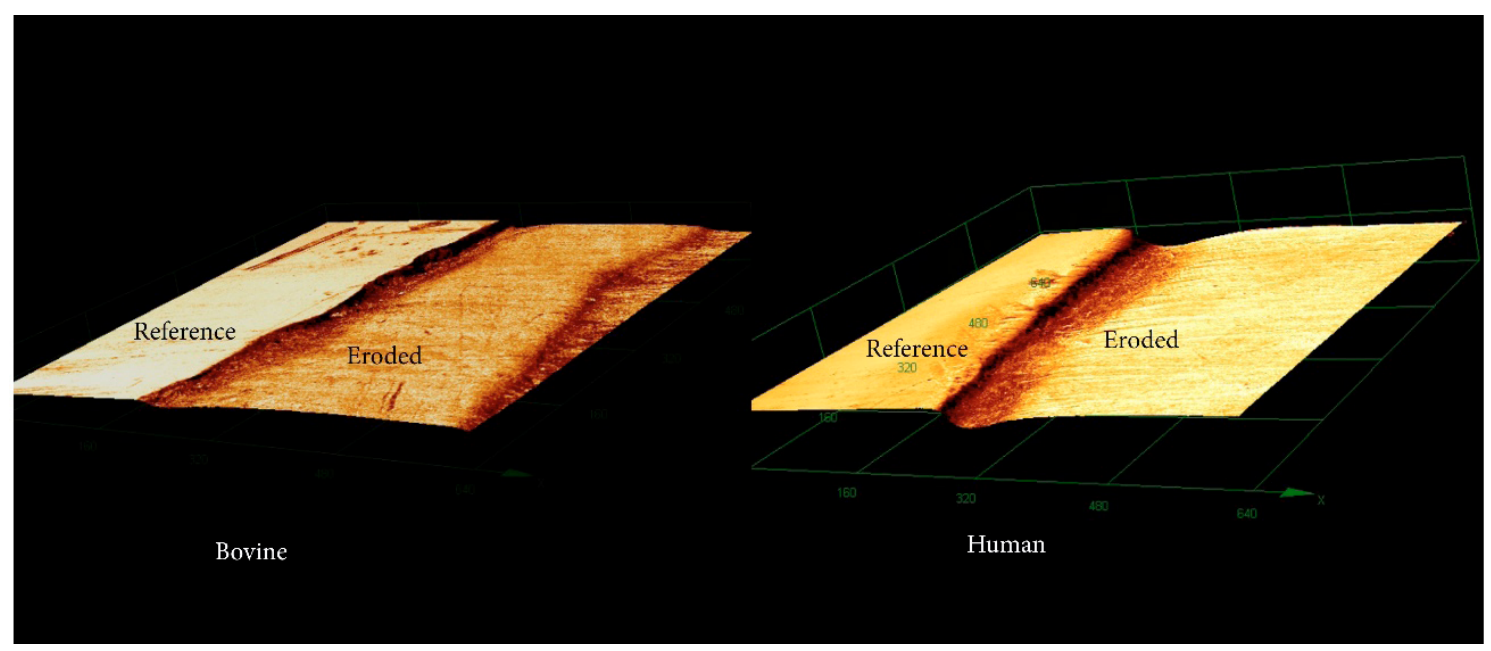

FIGURE 1 | Enamel erosion caused by $\mathrm{gHCl}$ in bovine and human enamel substrates.

\section{DISCUSSION}

Reflux episodes are composed of liquid and gaseous reflux ${ }^{22}$ and of mixed liquid-gas. In resting subjects, at least half of all reflux events are associated with gas reflux. ${ }^{10,28}$ An isolate episode of acid reflux into the oral cavity does not lead to a pathological condition. However, if reflux episodes occur on a regular basis over a long period, they are characterized as gastroesophageal reflux disease (GERD) and the risk of developing teeth erosion increases. ${ }^{29}$

The damaging effects of liquid hydrochloric acid on tooth surface is known, ${ }^{30}$ and many studies have been performed on the prevention of erosive lesions on both dentin and enamel..$^{31,32}$ Due to the constant presence of gas reflux episodes, it is important to evaluate the effect of hydrochloric acid on the enamel surface. This study was performed using a new method, since there are no reports in the literature about the effect of gaseous hydrochloric acid on enamel dental erosion. Only a previous study ${ }^{27}$ analyzed erosion using gaseous hydrochloric acid in dentin. This study showed that $\mathrm{gHCl}$ can promote enamel demineralization as seen in Figure 1, in which structural loss and surface demineralization can be observed.

Many studies reported that the gas enhance the painful symptoms of GERD ${ }^{12,33}$ because it produces na 
increased distension of the esophagus, reaching the proximal esophagus ${ }^{16}$, and the presence of gas in the refluxate increases the probability of reflux perception in patients. ${ }^{12}$ The gas reaches the oral cavity more easily than liquid ${ }^{16}$ and, in most cases of GERD, the refluxate remains in the esophagus and occasionally comes in direct contact with the oral cavity.

The association between GERD and tooth erosion is stronger than commonly noticed by physicians, ${ }^{34}$ being difficult to establish whether tooth enamel damage occurs over a long period and is influenced by multiple factors. ${ }^{35}$

Analyzing GERD erosive potential, in vivo studies showed high prevalence of dental erosion in patients with GERD. ${ }^{36,37}$ These results cannot be associated with both liquid and gaseous refluxate. In vitro and in situ studies performed with liquid hydrochloric acid observed dental loss after $\mathrm{pH}$ cycling in $\mathrm{HCl},{ }^{31,32}$ showing its erosive potential. Bartlett and Coward ${ }^{30}$ performed a study comparing erosive potential of gastric juice with a soft drink and observed that gastric juice has a greater potential for enamel and dentin erosion than a carbonated drink.

A study on animal models found that the liquid hydrochloric acid is not solely responsible for dental erosion and that the existence of steam coming from the acid gastric juice may be the most important factor. ${ }^{38}$ In our study, after the erosive challenges, we observed that the $\mathrm{gHCl}$ caused severe wear and increased roughness in bovine $(11.5 \mu \mathrm{m}$ and $2.6 \mu \mathrm{m})$ and human $(11.4 \mu \mathrm{m}$ and $3.3 \mu \mathrm{m})$ enamel surface, respectively. No studies that analyzed the erosive effect of gaseous hydrochloric acid on the enamel surface were found, making it impossible to compare this result.

In our study, the erosive challenges were performed in bovine and human enamel, because it is necessary to know the action of gaseous hydrochloric acid on both kinds of enamel surfaces. Usually, human teeth are preferred for in vitro and in situ dental studies because of the approximation with clinical occurrences. However, the use of human teeth has disadvantages and limitations, such as difficulties to get them in sufficient quantity and with adequate quality; ${ }^{25}$ the age of the collected human teeth, which might lead to greater variations in the outcome measures of the study; some anatomic form limitations, ${ }^{39}$ infection hazard ${ }^{40}$, and ethical issues. ${ }^{41}$

Bovine teeth are used in many studies since they are easy to obtain in high quantities, present good condition (absence of caries) and larger surfaces. ${ }^{42}$ However, there are some concerns about the application of data obtained from bovine teeth because their chemistry and structure are not identical to the human teeth. ${ }^{25,26}$ Bovine teeth have lower fluoride concentration compared with human teeth and greater porosity, which results in faster diffusion and formation of caries lesions. ${ }^{25}$ Regarding radiographic density, bovine enamel has higher density and the bovine coronal dentin has less radiodensity compared with human teeth. ${ }^{26}$

Despite the differences between these two substrates, bovine enamel can be considered a valide substitute for tooth enamel in most in vitro studies. It provides more consistent experimental response, since its composition is less variable compared with human enamel. ${ }^{25}$

In the literature, there are a few studies that compare the demineralization pattern between bovine and human teeth; 43 however, one study showed there was no difference between these two substrates analyzing dental wear caused by citric acid $^{44}$ and in a study comparing bovine and human dentin in erosion/abrasion tests..$^{32}$

The effects of hydrochloride acid on bovine dental enamel show that the demineralization pattern is cyclic. The initial demineralization is rapid due to great number of hydroxyapatite crystals with small diameters. As these crystals are removed, the larger diameter of the remaining ones decrease the demineralization rate, then with the exposure of small crystals, demineralization rate 
increases again. ${ }^{45}$ Other study showed that bovine enamel exposed to $\mathrm{HCl}$ in a brief time incubation presented linear phosphate dissolution in a time and $\mathrm{pH}$ dependent manner. ${ }^{46}$

Studies that used human enamel to investigate the effects of $\mathrm{HCl}$ acid on tooth surface showed that $\mathrm{HCl}$ caused interprismatic destruction after 5 minutes of acid exposure. ${ }^{47}$ Teeth etching with $\mathrm{HCl} 15 \%$ for 2 minutes decreased the carbonate content of enamel ${ }^{48}$ and lengthening of etching time enhanced the depth of erosion surface, proving that structure alterations caused by $\mathrm{HCl}$ are time-dependent. ${ }^{49}$

From the data obtained from the studies that evaluated the effects of $\mathrm{HCl}$ on bovine and human enamel, ${ }^{46-49}$ we observed that despite having different structure, both suffered time-dependent structural changes and mineral loss. This study evaluated other parameters but also found similar responses in both substrates, confirming that bovine teeth are a reliable substitute for human teeth in in vitro studies on erosion.

\section{CONCLUSION}

This study showed the gaseous hydrochloric acid effect on dental enamel is similar in bovine and human teeth. Microhardness, wear profile, step and roughness analysis showed similarity of results, thus in situ studies on dental erosion and its association with GERD can be performed using both dental substrates. Since human teeth are more difficult to acquire, bovine teeth is a safe substitute for human enamel.

\section{ACKNOWLEDGEMENTS}

This study was supported by FAPESP (Fundação de Amparo à Pesquisa do Estado de São Paulo). Process number 2010/19531-8 and 2011/12901-7.

\section{CONFLICT OF INTEREST}

The authors declare no conflict of interest.

\section{REFERENCES}

1. Bor S. Reflux esophagitis, functional and non-functional. Best Pract Res Clin Gastroenterol. 2019;40-41:101649. doi: 10.1016/j.bpg.2019.101649.

2. Richter JE, Rubenstein JH. Presentation and epidemiology of gastroesophageal reflux disease. Gastroenterol. 2018;154(2):267-76. doi: 10.1053/j.gastro.2017.07.045.

3. Sandhu DS, Fass R. Current trends in the management of gastroesophageal reflux disease. Gut Liver. 2018;12(1):7-16. doi: 10.5009/gnl16615.

4. Schoeman MN, Tippett MDM, Akkermans LMA, Dent J, Holloway RH. Mechanisms of gastroesophageal reflux in ambulant healthy human subjects. Gastroenterol. 1995;108(1):83-91. doi: 10.1016/0016-5085(95)90011-X.

5. Penagini R, Schoeman M, Dent J, Tippett M, Holloway R. Motor events underlying gastro-oesophageal reflux in ambulant patients with reflux oesophagitis. Neurogastroenterol Motil. 1996;8(2):131-41. doi: 10.1111/j.1365-2982.1996.tboo253.x.

6. Kaye MD. Postprandial gastro-oesophageal reflux in healthy people. Gut. 1977;18(9):709-12. doi: 10.1136/gut.18.9.709.

7. Masclee AAM, De Best ACAM, De Graaf R, Cluysenaer OJJ, Jansen JBMJ. Ambulatory 24-hour pH-metry in the diagnosis of gastroesophageal reflux disease: determination of criteria and relation to endoscopy. Scand J Gastroenterol. 1990;25(3):225-30. doi: 10.1080/00365521.1990.12067095.

8. Dent J, Holloway R, Toouli J, Dodds W. Mechanisms of lower oesophageal sphincter incompetence in patients with symptomatic gastrooesophageal reflux. Gut. 1988;29(8):1020-8. doi: 10.1136/gut.29.8.1020.

9. Sifrim D, Blondeau K. Technology insight: the role of impedance testing for esophageal disorders. Nat Clin Pract Gastroenterol Hepatol. 2006;3(4):210-9. doi: 10.1038/ncpgasthepo446.

10. Sifrim D, Silny J, Holloway R, Janssens J. Patterns of gas and liquid reflux during transient lower oesophageal sphincter relaxation: a study using intraluminal electrical impedance. Gut. 1999;44(1):47-54. doi: 10.1136/gut.44.1.47.

11. Van Wijk MP, Sifrim D, Rommel N, Benninga MA, Davidson GP, Omari TI. Characterization of intraluminal impedance patterns associated with gas reflux in healthy volunteers. Neurogastroenterol Motil. 2009;21(8):825-e55. doi: 10.1111/j.1365-2982.2009.01289.x.

12. Emerenziani S, Sifrim D, Habib FI, Ribolsi M, Guarino MPL, Rizzi M, et al. Presence of gas in the refluxate enhances reflux perception in non-erosive patients with physiological 
acid exposure of the oesophagus. Gut. 2008;57(4):443-7. doi: 10.1136/gut.2007.130104.

13. Foroutan M, Zojaji H, Ehsani M, Darvishi M. Advances in the Diagnosis of GERD Using the Esophageal pH Monitoring, Gastro-Esophageal Impedance-pH Monitoring, And Pitfalls. Open Access Maced J Med Sci. 2018;6(10):1934-40. 2018. doi: 10.3889/oamjms.2018.410.

14. Pohl D, Tutuian R. Reflux monitoring: pH-metry, Bilitec and oesophageal impedance measurements. Best Pract Res Clin Gastroenterol. 2009;23(3):299-311. doi: 10.1016/ j.bpg.2009.04.003.

15. Sifrim D, Holloway R, Silny J, Xin Z, Tack J, Lerut A, et al. Acid, nonacid, and gas reflux in patients with gastroesophageal reflux disease during ambulatory 24-hour pH-impedance recordings. Gastroenterol. 2001;120(7):1588-98. doi: 10.1053/gast.2001.24841.

16. Tutuian R, Vela MF, Hill EG, Mainie I, Agrawal A, Castell DO. Characteristics of symptomatic reflux episodes on acid suppressive therapy. Am J Gastroenterol. 2008;103(5):1090-6. doi: 10.1111/j.1572-0241.2008.01791.x.

17. Koukias N, Woodland P, Yazaki E, Sifrim D. Supragastric belching: prevalence and association with gastroesophageal reflux disease and esophageal hypomotility. J Neurogastroenterol Motil. 2015;21(3):398. doi: 10.5056/jnm15002.

18. Lee B, Lee SH, Jang D, Chung K, Hwang J-H, Jang S, et al. Belching during gastroscopy and its association with gastroesophageal reflux disease. Dis Esophagus. 2016;29(4):342-9. doi: 10.1111/dote.12326.

19. Ong AM-L, Chua LT-T, Khor CJ-L, Asokkumar R, Wang Y-T. Diaphragmatic breathing reduces belching and proton pump inhibitor refractory gastroesophageal reflux symptoms. Clin Gastroenterol Hepatol. 2018;16(3):407-16. e2. doi: 10.1016/j.cgh.2017.10.038.

20. Shimazu R, Yamamoto M, Minesaki A, Kuratomi Y. Dental and oropharyngeal lesions in rats with chronic acid reflux esophagitis. Auris Nasus Larynx. 2018;45(3):522-6. doi: 10.1016/j.anl.2017.08.011.

21. Kim TH, Lee KJ, Yeo M, Kim DK, Cho SW. Pepsin detection in the sputum/saliva for the diagnosis of gastroesophageal reflux disease in patients with clinically suspected atypical gastroesophageal reflux disease symptoms. Digestion. 2008;77(3-4):201-6. doi: 10.1159/000143795.

22. Clarrett DM, Hachem C. Gastroesophageal Reflux Disease (GERD). Mo Med. 2018;115(3):214-8.

23. Oliveira GC, Tereza GPG, Boteon AP, Ferrairo BM, Gonçalves PSP, Silva TC, et al. Susceptibility of bovine dental enamel with initial erosion lesion to new erosive challenges. PloS One. 2017;12(8):e0182347. doi: 10.1371/journal.pone.0182347.

24. Rios D, Honório HM, Magalhães A, Delbem A, Machado MAAM, Silva SMB, et al. Effect of salivary stimulation on erosion of human and bovine enamel subjected or not to subsequent abrasion: an in situ/ex vivo study. Caries Res. 2006;40(3):218-23. doi: 10.1159/oooo92229.

25. Mellberg JR. Hard-tissue substrates for evaluation of cariogenic and anti-cariogenic activity in situ. J Dent Res. 1992;71(3 Suppl):913-9. doi: 10.1177/002203459207100s25. 26. Tanaka JLO, Medici Filho E, Salgado JAP, Salgado MAC, Moraes LC, Moraes MEL, et al. Comparative analysis of human and bovine teeth: radiographic density. Braz Oral Res. 2008;22(4):346-51. doi: 10.1590/s1806-83242008000400011.

27. Toro CVT, Faraoni JJ, Matos LLM, Palma-Dibb RG. Efficacy of different strategies to treat root dentin eroded by liquid or gaseous hydrochloric acid associated with brushing abrasion. Arch Oral Biol. 2018;89:65-9. doi: 10.1016/ j.archoralbio.2018.02.005.

28. Clarke AT, Wirz AA, Manning JJ, Ballantyne SA, Alcorn DJ, McColl KE. Severe reflux disease is associated with an enlarged unbuffered proximal gastric acid pocket. Gut. 2008;57(3):292-7. doi: 10.1136/gut.2006.109421.

29. Schlueter N, Luka B. Erosive tooth wear-a review on global prevalence and on its prevalence in risk groups. Br Dent $J$ 2018;224(5):364-70. doi: 10.1038/sj.bdj.2018.167.

30. Bartlett DW, Coward PY. Comparison of the erosive potential of gastric juice and a carbonated drink in vitro. J Oral Rehabil. 2001;28(11):1045-7. doi: 10.1046/j.1365-2842.2001.00780.x.

31. Esteves-Oliveira M, Yu H, de Paula Eduardo C, Meister J, Lampert F, Attin T, et al. Screening of $\mathrm{CO}_{2}$ laser $(10.6 \mu \mathrm{m})$ parameters for prevention of enamel erosion. Photomed Laser Surg. 2012;30(6):331-8. doi: 10.1089/pho.2011.3175.

32. Wegehaupt FJ, Tauböck TT, Sener B, Attin T. Long-term protective effect of surface sealants against erosive wear by intrinsic and extrinsic acids. J Dent. 2012;40(5):416-22. doi: 10.1016/j.jdent.2012.02.003.

33. Bredenoord AJ, Weusten BL, Timmer R, Smout AJ. Characteristics of gastroesophageal reflux in symptomatic patients with and without excessive esophageal acid exposure. Am J Gastroenterol. 2006;101(11):2470-5. doi: 10.1111/ j.1572-0241.2006.00945.x.

34. Ranjitkar S, Smales RJ, Kaidonis JA. Oral manifestations of gastroesophageal reflux disease. J Gastroenterol Hepatol. 2012;27(1):21-7. doi: 10.1111/j.1440-1746.2011.06945.x. 
35. Ganesh M, Hertzberg A, Nurko S, Needleman H, Rosen R. Acid rather than non-acid reflux burden is a predictor of tooth erosion. J Pediatr Gastroenterol Nutr. 2016;62(2):309-13. doi: 10.1097/mpg.0000000000000927.

36. Farahmand F, Sabbaghian M, Ghodousi S, Seddighoraee N, Abbasi M. Gastroesophageal reflux disease and tooth erosion: a cross-sectional observational study. Gut Liver. 2013;7(3):278-81. doi: 10.5009/gnl.2013.7.3.278.

37. Wang G-R, Zhang H, Wang Z-G, Jiang G-S, Guo C-H. Relationship between dental erosion and respiratory symptoms in patients with gastro-oesophageal reflux disease. J Dent. 2010;38(11):892-8. doi: 10.1016/j.jdent.2010.08.001.

38. Higo T, Mukaisho K, Ling Z-Q, Oue K, Chen K-H, Araki Y, et al. An animal model of intrinsic dental erosion caused by gastrooesophageal reflux disease. Oral Dis. 2009;15(5):360-5. doi: 10.1111/j.1601-0825.2009.01561.x.

39. Zero D. In situ caries models. Adv Dent Res. 1995;9(3):214-30. doi: 10.1177/08959374950090030501.

40. Rueggeberg FA. Substrate for adhesion testing to tooth structure-Review of the literature: A report of the ASC MD156 Task Group on Test methods for the adhesion of restorative materials Accredited standards committee MD156 for dental materials and devices. Dent Mater. 1991;7(1):2-10. doi: 10.1016/0109-5641(91)90017-s.

41. Skene L. Ownership of human tissue and the law. Nat Rev Genet. 2002;3(2):145-8. doi: 10.1038/nrg725.

42. Steiger-Ronay V, Kuster IM, Wiedemeier DB, Attin T, Wegehaupt FJ. Erosive loss of tooth substance is dependent on enamel surface structure and presence of pellicle-an in vitro study. Arch Oral Biol. 2020;112:104686. doi: 10.1016/ j.archoralbio.2020.104686.
43. Laurance-Young P, Bozec L, Gracia L, Rees G, Lippert F, Lynch R, et al. A review of the structure of human and bovine dental hard tissues and their physicochemical behaviour in relation to erosive challenge and remineralisation. J Dent. 2011;39(4):266-72. doi: 10.1016/j.jdent.2011.01.008.

44. Field J, German M, Waterhouse P. Using bearing area parameters to quantify early erosive tooth surface changes in enamel: A pilot study. J Dent. 2013;41(11):1060-7. doi: 10.1016/j.jdent.2013.08.015.

45. Derceli JR, Faraoni JJ, Pereira-da-Silva MA, Palma-Dibb RG. Analysis of the early stages and evolution of dental enamel erosion. Braz Dent J. 2016;27(3):313-7. doi: 10.1590/0103-6440201600667.

46. Hannig C, Hamkens A, Becker K, Attin R, Attin T. Erosive effects of different acids on bovine enamel: release of calcium and phosphate in vitro. Arch Oral Biol. 2005;50(6):541-52. doi: 10.1016/j.archoralbio.2004.11.002.

47. Houghton JW, Yong JT, Carpenter G, Bartlett D, Moazzez R, O'Toole S. Differences in the Natural Enamel Surface and Acquired Enamel Pellicle following Exposure to Citric or Hydrochloric Acid. Caries Res. 2020;54(2):122-9. doi: 10.1159/000504746

48. Bertacci A, Lucchese A, Taddei P, Gherlone EF, Chersoni S. Enamel structural changes induced by hydrochloric and phosphoric acid treatment. J App Biomater Func. 2014;12(3):240-7. doi: 10.5301/jabfm.5000179.

49. Arnold WH, Haddad B, Schaper K, Hagemann K, Lippold C, Danesh G. Enamel surface alterations after repeated conditioning with $\mathrm{HCl}$. Head Face Med. 2015;11(1):1-7. doi: 10.1186/s13005-015-0089-2. 